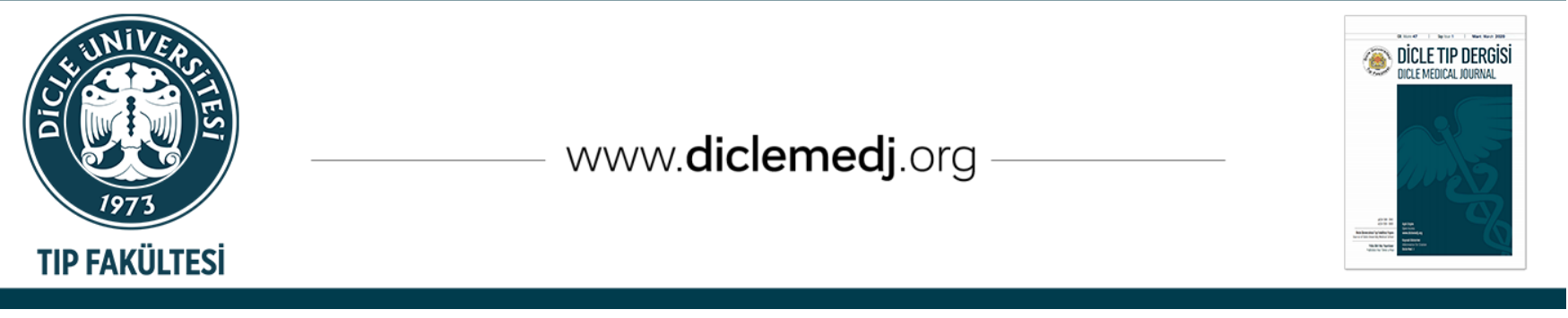

Original Article / Özgün Araştırma

\title{
A Comparison Of Manual Hemocytometry And Different Modes Of Mindray BC-6800 Hematology Analyzer For Cell Count In Peritoneal And Pleural Fluids
}

\author{
Ünsal Savcı ${ }^{1}{ }^{1}$, Mustafa Şahin ${ }^{\left(D^{2}\right.}$, Barış Eser ${ }^{\text {iD }}{ }^{3}$, Hüseyin Kayadibi ${ }^{D} 4$ \\ 1 Hitit University, Erol Olcok Education and Research Hospital, Medical Microbiology Laboratory, Corum, Turkey \\ 2 Hitit University, Erol Olcok Education and Research Hospital, Medical Biochemistry Laboratory, Çorum, Turkey \\ 3 Hitit University School of Medicine, Department of Nephrology, Çorum, Turkey
}

4 Hitit University School of Medicine, Department of Medical Biochemistry, Çorum, Turkey

Received: 24.09.2019; Revised: 07.05.2020; Accepted: 10.05.2020

\begin{abstract}
Objective: Total white blood cell (WBC) count in body fluids (BF) is important in diagnosis and treatment of inflammatory and infectious diseases. We aimed to compare hemogram and BF modes of Mindray BC-6800 hematology analyzer with the manual hemocytometry method for determination of total WBC count in peritoneal and pleural fluids.

Method: Our study consisted of a total of 143 specimens, 109 peritoneal fluid and 34 pleural effusion fluid. Each sample was analyzed consecutively twice, first with the manual method and, later with both hemogram mode and the BF mode of Mindray BC-6800 automated hematology analyzer.

Results: There was a statistically significant difference between manual count and hemogram mode (for peritoneal fluids $\mathrm{p}<0.001$, for pleural fluids $\mathrm{p}<0.001$ ). There was a statistically significant difference between the hemogram mode and BF mode too. (for peritoneal fluids $\mathrm{p}<0.001$, for pleural fluids $\mathrm{p}<0.001$ ). However, there was no statistically significant difference between the manual count and $\mathrm{BF}$ mode (for peritoneal fluids $\mathrm{p}=0.236$, for pleural fluids $\mathrm{p}=0.627$ ). Less than 100 cells $/ \mathrm{mL}$, there was a statistically significant difference between each of the counting methods (Manual count vs hemogram mode $p<0.001$, manual count vs BF mode $p=0.012$, hemogram mode vs BF mode $p<0.001$ ).
\end{abstract}

DOI: 10.5798/dicletip.755702

Correspondence / Yazıșma Adresi: Ünsal Savcl, Hitit University, Erol Olcok Education and Research Hospital, 19040, Çorum, Turkey e-mail: unsalsavci@gmail.com 
More than 100 cells/mL, there was no statistically significant difference between manual count and the BF mode (p= 0.332). However, there were statistically significant differences between manual count and hemogram mode, and hemogram mode and BF mode ( $\mathrm{p}=0.003$ and $\mathrm{p}<0.001$ respectively).

Conclusion: The use of manual method instead of hematology analyzer is more convenient in samples $<100$ cells $/ \mathrm{mL}$, and BF mode may be used as a screening tool in samples $>100$ cells $/ \mathrm{mL}$.

Keywords: Automated hematology analyzer, cell count, peritoneal fluid, pleural fluid, WBC.

\section{Peritoneal Ve Plevral Sıvılarda Hücre Sayımı İçin Manuel Hemasitometre İle Mindray BC- 6800 Hematoloji Analizörünün Farklı Modlarının Karşılaştırılması}

Öz

Amaç: Vücut sıvılarında (BF) toplam beyaz kan hücre (WBC) sayısı, enflamatuar ve bulaşıcı hastalıkların tanı ve tedavisinde önemlidir. Peritoneal ve plevral sıvılarda toplam WBC sayısının belirlenmesi için Mindray BC-6800 hematoloji analizörünün hemogram ve BF modlarını manuel hemositometri yöntemiyle karşılaştırmayı amaçladık.

Yöntemler: Çalışmamız 109 periton sıvısı ve 34 plevral efüzyon sıvısı olmak üzere toplam 143 örnekten oluşuyordu. Herbir örnek, önce manuel yöntemle ve daha sonra Mindray BC-6800 otomatik hematoloji analizörünün hemogram ve BF modları ile iki kez art arda analiz edildi.

Bulgular: Manuel sayım ve hemogram modu arasında istatistiksel olarak anlamlı farklılık vardı (periton sıvıları için p< 0.001, plevral sıvılar için $\mathrm{p}<0.001$ ). Hemogram modu ile BF modu arasında da istatistiksel olarak anlamlı bir fark bulundu (periton sıvıları için p< 0.001, plevral sıvılar için $\mathrm{p}<0.001$ ). Ancak manuel sayım ve BF modu arasında istatistiksel olarak anlamlı bir sonuç bulunamadı (Periton sıvıları için $\mathrm{p}=0.236$, plevral sıvılar için $\mathrm{p}=0.627$ ). 100 hücre/mL'den daha az olduğunda, her bir sayma yöntemi arasında istatistiksel olarak anlamlı farklılı mevcuttu (Manuel sayım \& hemogram modu p<0.001, manuel sayım \& BF modu p=0,012, hemogram modu \& BF modu p< 0.001). 100 hücre/mL'den fazla olduğunda, manuel sayım ve BF modu arasında istatistiksel olarak anlamlı bir farklılık yoktu ( $\mathrm{p}=0,332)$. Ancak manuel sayım ve hemogram modu arasında ve hemogram modu ve BF modu arasında arasında istatistiksel olarak anlamlı bir farklılık vardı (sırasıyla $p=0,003$ ve $p<0.001$ ).

Sonuç: Hematoloji analizörü yerine manuel metodun kullanılması, <100 hücre / mL'lik numunelerde daha uygundur ve BF modu > 100 hücre / mL'lik numunelerde bir tarama aracı olarak kullanılabilir.

Anahtar kelimeler: Otomatize hematoloji analizörü, hücre sayımı, peritoneal sıvı, plevral sıvı, WBC.

\section{INTRODUCTION}

Total WBC count in body fluids (BF) is important in diagnosis and management of neoplasms, hemorrhages, inflammatory and infectious diseases ${ }^{1,2}$.

Because, cell counting provides a valuable data in diagnosis and management of various diseases such as spontaneous bacterial peritonitis in patients with peritoneal dialysis and cirrhosis ${ }^{3}$. Furthermore, cell count is an expedient and cost-effective method for analyzing possible reasons of as cites and may help in classification of the pleural effusion ${ }^{4-6}$. Despite technological advances, most laboratories still use manual microscopy to count white and red cells.
BF cell counts are usually applied manually by using an improved Neubauer chamber ${ }^{7}$. Manual microscopy is accepted as the gold standard for the assessment and classification of cells in body fluids3. However, since manual cell count requires intensive labor that is time-consuming and due to low precision, significant differences between observers and need for service of qualified staff on a $24 / 7$ basis are among its disadvantages. Automation is considered as an answer to cope with such difficulties ${ }^{1}$. Recently, automated BF cell count systems which have the potential to replace methods of manual count in many cases since they mitigate differences between users and improve feedback time and accuracy have been developed8. 
Automated hematology analyzers have hemogram and body fluid mode. In these analyzers, because the blood samples studied contain higher concentrations of cells than body fluid samples, carryover is an important issue. For this reason, in body fluid mode, after each sample is studied, the analyzer is flushed with distilled water to prevent the effect of the previous sample (carryover effect) ${ }^{1}$.

In this study, we aimed to compare the manuel BF cell count with the hemogram and BF modes of BC-6800 which is an automated hematology analyzer equipped with a specific mode for BF analysis. Most of the samples were composed of continuous ambulatory peritoneal dialysis (CAPD) fluids (110/155), and to our best knowledge, there is a limited number of published articles focused on analysis of CAPD fluids with Mindray BC-68003.

\section{METHODS}

Our study consisted of a total of 143 samples, 109 peritoneal fluid and 34 pleural effusion fluid. Our study received ethics committee approval of the date 12/19/2017 and decision number 2017-198 from the Hitit University School of Medicine Clinical Studies Ethics Committee. Administrative permission was taken by the letter of the number $40600303 / 604.02$ from the Hitit University Corum Erol Olcok Training and Research Hospital. The study was done in compliance with the CLSI document H56-A number 6 and suggestions of the International Council for Standardization in Hematology and the Helsinki Declaration.

\section{Study population}

The dialysate fluid taken for peritonitis diagnosis and treatment follow-up of patients who were admitted to the nephrology outpatient clinic and receiving peritoneal dialysis treatment due to the terminal renal failure was used as the peritoneal fluid. Pleural fluid samples were obtained from patients subjected to diagnostic thoracentesis for pleural effusion etiology. Samples were collected in tubes containing K3 EDTA, and were lightly mixed 6 to 8 times. Samples were not preprocessed and each sample admitted to the laboratory was analyzed within an hour. For sanguineous or cloudy samples, due to high concentrations of erythrocyte and/or WBC, dilution was applied prior to manual and automated analysis. Each sample was analyzed consecutively twice, first with the manual method and, later with both hemogram and the BF modes of Mindray BC-6800 automated hematology analyzer.

\section{Cell count with the Neubauer chamber}

In our study, the Neubauer chamber was used for manual cell count by the same researcher. Neubauer chamber has two counting areas on it. These two counting areas are separated by a groove. Corners of each of these counting areas have four sections (large squares) of $1 \mathrm{~mm} 2$ which are divided into 16 medium squares (for leucocyte count).

A clean lamella was placed on the Neubauer chamber, then 10 microliters of the body fluid sample was taken by automated pipettes with calibration certification and was pipetted from under the lamella to the Neubauer chamber without any air bubbles. Sample rapidly filled between the lamella and the striped area of the Neubauer chamber. Five minutes were given to the cells for settling on the lamella. By a microscope with 100x magnification, cells were checked for homogenous diffusion, and the microscope was switched to $400 \mathrm{x}$ magnifications for the count. Leucocytes were counted in one of the four sections composed by 16 squares on sides of the Neubauer chamber. Cell counts obtained from counting were multiplied with 10 to calculate the cell number in a volume of $1 \mathrm{~mm} 3$. Microscopic assessments of WBC counts were made directly or by diluting with Turk's solution. 
Cell count with the Mindray BC-6800 automated hematology analyzer

Targeted fluid cells, following reaction with reagents, were counted three-dimensionally by using laser ray scattering from two angles and fluorescent signals. Three-dimensional scattering diagram is very important for better identification and sorting of cell populations. It may particularly determine an abnormal cell population that cannot be detected by other techniques. BF mode of the Mindray BC-6800 analyzer uses SF cube technology and enables identification and detection of WBC count, cell ranges and nuclear cells. Targeted cells are subjected to 3D analysis by using fluorescence flow cytometric signals and data coming from two angles of the laser scanner. In BF mode, WBC and total nuclear cell counting is applied directly from the DIFF channel and cell counts and percentages of mononuclear, polymorphnuclear and high-fluorescence cells are classified. After studying each BF sample in the hematology analyzer, a blank sample was studied to prevent carryover effect. Macroscopic images of samples and leucocyte morphologies and clustering were assessed in addition to cell count.

\section{Statistical Analysis}

All statistical analyses were performed using the SPSS 22.0 package for Windows (IBM Corp.; Armonk, NY, USA). Demographic and biochemical features were classified as continuous or categorical variables as appropriate. Kolmogorov Smirnov analysis was used to test the normality. Since there was no Gaussian distribution, data were presented as median (25th-75thInter Quartile Range), and comparisons between groups were tested with Friedman's two-way ANOVA and Wilcoxon signed rank test. Spearman correlation analysis was used for the associations. All reported pvalues were two-tailed, and those less than 0.05 were considered statistically significant.

\section{RESULTS}

Samples from 143 patients comprised of 109 peritoneal and 34 pleural effusion fluids taken from 81 (57\%) male and 62 (43\%) female patients referred to our hospital's central laboratory from clinics and the emergency room was included in our study. Median ages of all, peritoneal and pleural effusion fluid donor patients were $58 \pm 16,54 \pm 14$ and $72 \pm 15$, respectively.

It was observed that median WBC counts of peritoneal fluids were considerably lower than the results of pleural fluids. Median WBC count of peritoneal fluids in the hemogram mode was 10 times more than the results of other two methods. However, median WBC counts in pleural fluids were similar in each of the three methods (Table I).

Table I: Total WBC counts of peritoneal and pleural fluids

\begin{tabular}{|lccc|}
\hline & $\begin{array}{l}\text { Hemogram } \\
\text { mode } \\
\text { Median } \\
\left.75^{\text {th }} \text { IQR }\right)\end{array}$ & Body fluid mode \\
$\left(25^{\text {th- }}-\right.$ & $\begin{array}{l}\text { Median }\left(25^{\text {th }}-75^{\text {th }}\right. \\
\text { IQR })\end{array}$ & $\begin{array}{c}\text { Manual } \\
\text { count } \\
\text { Median } \\
\left(25^{\text {th }}-75^{\text {th }}\right. \\
\text { IQR })\end{array}$ \\
\hline $\begin{array}{l}\text { Peritoneal } \\
\text { fluid(cells/mL) }\end{array}$ & $40(20-85)$ & $4(1-31)$ & $3(0-30)$ \\
$\begin{array}{l}\text { Pleural } \\
\text { fluid(cells/mL) }\end{array}$ & $675(343-2,260)$ & $539(298-1,931)$ & $\begin{array}{c}500(294- \\
1,893)\end{array}$ \\
Total(cells/mL) & $60(30-390)$ & $11(2-332)$ & $10(0-340)$ \\
\hline IQR: Inter Quartile Range & &
\end{tabular}

There was a statistically significant difference between manual count and hemogram mode for the peritoneal and pleural fluids. There was a statistically significant difference between the hemogram and BF modes. However, there was no statistically significant difference between the manual count and BF mode (Table II).

Table II: Comparison of Mindray BC-6800 modes and manual method

\begin{tabular}{|lcccc|}
\hline & & All body fluids & $\begin{array}{c}\text { Peritoneal } \\
\text { fluid }\end{array}$ & $\begin{array}{c}\text { Pleural } \\
\text { effusion }\end{array}$ \\
\cline { 2 - 5 } & & $p$ & $p$ & $p$ \\
\hline $\begin{array}{l}\text { Manual count } \\
\text { Hemogram mode }\end{array}$ & $<0.001$ & $<0.001$ & $<0.001$ \\
$\begin{array}{l}\text { Manual count vs } \\
\text { mode } \\
\begin{array}{l}\text { Hemogram mode vs BF } \\
\text { mode }\end{array}\end{array}$ & 0.613 & 0.236 & 0.627 \\
\hline
\end{tabular}

BF: Body fluid 
Based on the manual cell count method, accepted as a gold standard in cell counting, both hemogram and the body fluid modes were positively correlated with the manual count (Table III).

Table III: Correlation among the different cell count types

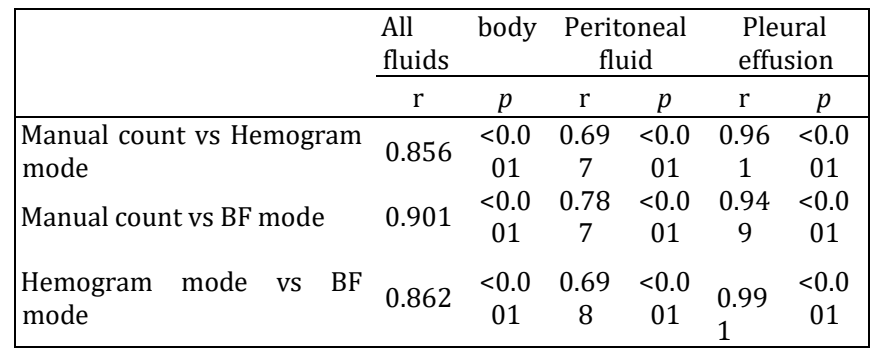

BF: Body fluid

Less than 100 cells $/ \mathrm{mL}$, there was a statistically significant difference between each of the counting methods (Manual count vs hemogram mode $\mathrm{p}<0.001$, manual count vs BF mode $\mathrm{p}=$ 0.012 , hemogram mode vs BF mode $p<0.001$ ). More than 100 cells $/ \mathrm{mL}$, there was no statistically significant difference between manual count and the body fluid mode ( $\mathrm{p}=$ 0.332).

However, there were statistically significant differences between manual count and hemogram mode, and hemogram mode and BF mode $(\mathrm{p}=0.003$ and $\mathrm{p}<0.001$ respectively) (Tables IV and V).

Table IV: Comparison of Mindray BC-6800 modes and manual method for $<100$ cells $/ \mathrm{mL}$ or $>100$ cells $/ \mathrm{mL}$ conditions

\begin{tabular}{|c|c|c|c|}
\hline & $\begin{array}{l}\text { Hemogram } \\
\text { mode }\end{array}$ & BF mode & $\begin{array}{c}\text { Manual } \\
\text { count }\end{array}$ \\
\hline & $\begin{array}{l}\text { Median } \quad\left(25^{\text {th }}-\right. \\
\left.75^{\text {th }} \text { IQR }\right)\end{array}$ & $\begin{array}{l}\text { Median (25 th- } \\
\left.75^{\text {th }} \text { IQR }\right)\end{array}$ & $\begin{array}{l}\text { Median } \\
\left(25^{\text {th }}-75^{\text {th }}\right. \\
\text { IQR })\end{array}$ \\
\hline $\begin{array}{l}<100 \\
\text { cells } / \mathrm{mL} \\
(\mathrm{n}=95)\end{array}$ & $30(20-60)$ & $3(1-11)$ & $2(0-10)$ \\
\hline $\begin{array}{l}>100 \\
\text { cells } / \mathrm{mL} \\
(\mathrm{n}=48)\end{array}$ & $810(360-2203)$ & $\begin{array}{c}612(319- \\
1964)\end{array}$ & $\begin{array}{c}685(318- \\
1830)\end{array}$ \\
\hline
\end{tabular}

Table V: Comparison of Mindray BC-6800 modes and manual method for $<100$ cells/mLor $>100$ cells $/ \mathrm{mL}$ conditions

\begin{tabular}{|c|c|c|}
\hline & $\begin{array}{l}<100 \\
\text { cells } / \mathrm{mL}\end{array}$ & $\geq 100$ cells $/ \mathrm{mL}$ \\
\hline & $p$ & $p$ \\
\hline $\begin{array}{l}\text { Manual count } \\
\text { Hemogram mode }\end{array}$ & $<0.001$ & 0.003 \\
\hline Manual count vs BF mode & 0.012 & 0.332 \\
\hline $\begin{array}{l}\text { Hemogram mode vs BF } \\
\text { mode }\end{array}$ & $<0.001$ & $<0.001$ \\
\hline
\end{tabular}

BF: Body fluid

\section{DISCUSSION}

In the present study we found that only BF mode cell count results were compatible with the manual count that is a gold standard method for cell counting. Automatic count of the body fluid was firstly applied in 1970, but couldn't become a focus of interest 7,9 . In subsequent years, improved analyzers were manufactured and their use at laboratories has become more common. Manual hemocytometry used in analysis of body fluids requires intensive labor, is time-taking and may have low repeatability ${ }^{10}$. Hematology analyzers automatically calculate cell count and accordingly, eliminate any time and labor needs or possible errors associated with manual cell count and calculation. Furthermore, it doesn't require pre-analytical sample preparations. In automated analyzers, transformation from the blood mode to the BF mode (includes automated rinsing cycles and background check) takes approximately two minutes, and processing a sample takes only one minute. Automated hematology analyzers appear as candidates to replace the manual hemocytometry methodology that requires intensive labor. Nevertheless, challenges associated with automated hematology analyzers at cell count in various BF samples, particularly where cell concentration is very low have been experienced ${ }^{11}$. Some of the hematology analyzers have only hemogram mode. On the other hand, in certain events, clinicians make their body fluid analysis requests in the hemogram mode and this is 
commonly observed. In the literature, we could encounter no study where body fluids are worked with the hemogram mode. Therefore, assessment of performance for the manual count with performances of hemogram and BF modes of hematology analyzers is very important. Fuster et al. ${ }^{3}$ assessed continuous ambulatory peritoneal dialysis fluid, ascites and pleural fluids with the Mindray BC-6800 hematology analyzer, and reported that there is no statistically significant difference between median WBC counts with the BC-6800 BF mode and manual count for all three body fluids. There was also a positive linear correlation between them $(r=0.94$ and $r=0.99$, respectively). Walker et al. ${ }^{12}$ compared Neubauer hemacytometer count with the Iris IQ200 BF mode (Iris Diagnostics, Chatsworth, $\mathrm{CA}$ ) and concluded that there was a positive linear correlation $(\mathrm{r}=0.998)$ between WBC counts. In our study, similar to previous studies, there was no statistically significant difference between the manual count and BF mode for both peritoneal and pleural fluids in addition to a positive linear correlation $(\mathrm{r}=0.787$ and $r=949$, respectively). Even though hemogram mode showed a positive linear correlation with the BF mode and manual count $(\mathrm{r}=0.697$ and $r=0.991$, respectively), there was a statistically significant difference between them. It was observed that the use of hemogram mode was not reliable for cell count in peritoneal and pleural fluids. Since hematology analyzers normally work with blood samples of higher cell concentrations, considered background cell concentration and elimination of carryover are important issues ${ }^{1}$. Published data are not precise enough to argue that current automated cell counters are reliable and have sufficient precision for low WBC counts in body fluids. Nevertheless, manual hemocytometry counting is also imprecise in low cell concentrations ${ }^{1}$. Results of our study conform to the limited precision of automated cell counters in low cell concentrations as shown by previous studies. In peritoneal dialysis fluid of patients receiving peritoneal dialysis treatment, WBC count more than 100 cells $/ \mathrm{mL}$ and/or $\geq 50 \%$ neutrophil is an argument acceptable for peritonitis and constitutes a cut-off value ${ }^{12,13}$. De Smet et al. ${ }^{1}$, in their study using the Cell-Dyn Sapphire hematology analyzer, reported that for WBC counts of 50 cells $/ \mu \mathrm{L}$, the functional sensitivity is troublesome for cerebrospinal fluid specimens, which often fall below this cut-off and are clinically considered abnormal at WBC counts of more than 5 cells $/ \mu \mathrm{L}$ and $>30$ cells $/ \mu \mathrm{L}$ for adults and for children, respectively. In our study, median WBC counts in peritoneal fluids were fairly below the threshold points mentioned, and WBC count was low. Results in our study also showed that use of Mindray BC6800 hematology analyzer for WBC count was not reliable for body fluids such as peritoneal and pleural fluids containing cell counts below the cut-off threshold of 100 cells $/ \mathrm{mL}$. Cell count helps in determination of differential diagnoses between transudate $(\mathrm{WBC}<1000 / \mu \mathrm{L})$ and exudate $(\mathrm{WBC}>1000 / \mu \mathrm{L})^{3}$. In our study, WBC concentration in pleural fluids was fairly high and above the 100 cells $/ \mu \mathrm{L}$ cut-off value. Similar to previous studies, Mindray BC-6800 BF mode showed reliable WBC count results for median pleural fluids above this cut-off value. Another problem we encountered in our study was WBC clustering in samples. Mindray BC-6800 showed a false low in WBC count of such samples. However, at manual count of clustered samples, we observed that cell count and sorting was made much easier with the human eye. Furthermore, human eye was able to sort clinically significant new and old cells. These aspects may be considered as advantages of manual count over automated analyzers. Not using different automated hematology analyzers, lack of manual count by an additional researcher, failure to calculate the kappa value, lack of classifying the leucocyte sub-classes with dyeing techniques and use of analyzers, failure to calculate the cut-off point due to WBC count 
of zero in $29.4 \%$ of the samples (42/143) and lack of calculating the differences for erythrocyte counts since more than $40 \%$ of samples had zero erythrocyte and the adjustment of the Mindray BC-6800 software just for three decimals in million, which is not proper for samples that has less than 10.000 erythrocyte/mL are among the limitations of our study.

In conclusion, we advise to use the manual method instead of an automated analyzer for samples with $<100$ cells $/ \mathrm{mL}$. For samples with $\geq 100$ cells $/ \mathrm{mL}$, use of BC-6800 BF mode for total WBC counts of body fluid samples may be fairly efficient. We hold the view that Mindray BC-6800 hemogram mode cannot be used for analysis of body fluids. It shall be advantageous to prefer hematology analyzers with BF mode in set-up and procurement processes for laboratories.

This study was presented as an oral presentation at the Internationally participated Congress\&Lab Expo 2018 in Antalya on October 3, 2018.

Ethics Committee Approval: Our study received ethics committee approval of the date 12/19/2017 and decision number 2017-198 from the Hitit University School of Medicine Clinical Studies Ethics Committee. Administrative permission was taken by the letter of the number 40600303/604.02 from the Hitit University Corum Erol Olcok Training and Research Hospital.

Conflicts of interest: The authors have no conflict of interests to declare.

Financial Disclosure: The authors declared that this study has received no financial support

\section{REFERENCES}

1. De Smet D, Van Moer G, Martens GA, et al. Use of the Cell-Dyn Sapphire hematology analyzer for automated counting of blood cells in body fluids. Am J Clin Pathol. 2010; 133: 291-9.

2. Cognialli RCR, Comar SR, Souza AMD, Singer GMB. Evaluation of pleural and ascitic fluid analysis on the Sysmex XE-5000 hematology analyzer. J Bras Patol Med Lab. 2017; 53; 150-8.

3. Fuster O, Andino B, Pardo A, Laiz B. Continuous ambulatory peritoneal dialysis, ascitic and pleural body fluids evaluation with the Mindray BC-6800 hematology analyzer. Journal of clinical laboratory analysis. J Clin Lab Anal. 2018; 32: e22240.

4. Runyon BA. Management of adult patients with ascites due to cirrhosis: an update. Hepatology. 2009; 49: 2087-107.

5. Conner BD, Lee YG, Branca P, Rogers JT, Rodriguez RM, Light RW. Variations in pleural fluid WBC count and differential counts with different sample containers and different methods. Chest. 2003; 123: 1181-7.

6. Bottini PV, Garlipp CR, Nogueira BF, Pompeo DB, Souza MI (2018). Performance evaluation of a new generation of automated analyzer for pleural and peritoneal fluids cytology. Clin Lab. 2018; 64: 17836.

7. Schonenberg $H$, Fassl $H$. Comparison of the coulter-counter-method and the counting-chamber to determine the cell count of the cerebrospinal fluid. Arztliche Forschung. 1970; 24: 118.

8. Walker TJ, Nelson LD, Dunphy BW, Anderson DM, Kickler TS. Comparative Evaluation of the Iris iQ200 Body Fluid Module With Manual Hemacytometer Count. Am J Clin Pathol. 2009; 131: 333-8.

9. Talstad I. Electronic counting of spinal fluid cells. Am J Clin Pathol. 1984; 81: 506-11.

10. Aune MW, Becker JL, Brugnara $\mathrm{C}$, et al. Automated flow cytometric analysis of blood cells in cerebrospinal fluid. Am J Clin Pathol. 2004; 121: 690-700.

11. Takemura H, Ai T, Kimura K, et al. Evaluation of cell count and classification capabilities in body fluids using a fully automated Sysmex XN equipped with high-sensitive Analysis (hsA) mode and DI-60 hematology analyzer system. PloS one. 2018; 13 : e0195923. 
12. Li PKT, Szeto CC, Piraino B, et al. Peritoneal dialysis-related infections recommendations: 2010 update. Perit Dial Int. 2010; 30: 393-423.
13. Fleming $\mathrm{C}$, Russcher $\mathrm{H}$, Lindemans J, de Jonge R. Clinical relevance and contemporary methods for counting blood cells in body fluids suspected of inflammatory disease. Clin Chem Lab Med. 2015; 53: 1689-706. 